\title{
Concern as revived 1918 flu virus kills monkeys
}

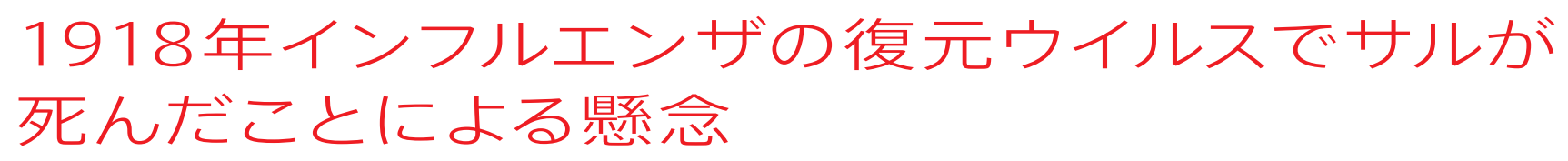

Nature Vol.445 (237) / 18 January 2007

KerriSmith

「スペイン風邪」ともよばれる 1918 年のイ ンフルエンザでは世界中で約 5000 万人が 死亡したが、そのウイルスを実験室でマカク ザルに感染させると死に至ることが報告され た。この研究は、2005 年の Natureに掲載 されて議論をよんだウイルス塩基配列の論 文 ${ }^{1} 、$ おび遺体からのウイルスの採取・復 元とこのウイルスの病原性をマウスで評価し た Science の論文 ${ }^{2}$ の後に続くものである。

このような恐ろしいウイルスを復元する ことの意義について疑問視する科学者もい る。リスクを上回るだけのメリットが果た してあるのだろうか。

今回のマカクザル実験を行った研究者た ちによれば、その答えは「イエス」だという。 ヒトに似た生物の体内でこのウイルスがど のように振る舞うかをよく理解することが、 必ずや将来の世界的大流行に対する備えに なるというのだ。この研究は、カナダ公衆 衛生局（ウィニペグ）にあるレベル４のバ イオハザード実験室で実施された。ウィス コンシン大学マディソン校 (米) の河岡義 裕たちは、マカクザルに 1918 年のウイル スまたは現代のインフルエンザウイルスを 感染させた ${ }^{3}$ 。現代のウイルスは肺に軽度 の症状を生じさせるにとどまったが、1918 年のウイルスは短時間で呼吸器系全体に広 がり、感染したマカクザルは数日以内に死 んでしまった。この重篤な症状は1918 年 のヒト患者についての報告とよく似ている。

研究チームの報告によると、1918 年のウ イルスはサルの免疫系を暴走させ、その結果、 異常なほど大量に発現した免疫タンパク質が 体を攻撃した。つまり、免疫学者のいう「サ イトカインの嵐」が引き起こされたのである。

この研究は、1918 年のインフルエンザが、 大規模な自己免疫応答をも引き起こす西ナ イルウイルスなどと似た機構で病原性を発 揮する可能性を示唆している。このことから 治療の方向性をうかがい知ることができる、 とテキサス大学サウスウェスタン医療セン
ター (米) のウイルス学者である Michael Gale は話す。暴走した免疫応答を標的とす る薬剤は、現在ほかの疾患で適用を目指し て開発中であり、その中にはインターロイキ ン 6 という免疫タンパク質を制御する薬剤 などがある。こうした薬剤を少し手直しす れば、世界的大流行を起こす沉流行インフ ルエンザに太刀打ちできるかもしれない。

しかし、治療の方向性は見いだせたものの、 今回の研究結果はすでにマウスで得られてい た知見をなぞったものであり、もっと重要な 取り組むべき問題があると Gale は感じてい る。「発症機序には確かに関心をそそられる」 とGaleはいう。「しかし肝心かなめの問題は、 どうやって 1918 年のインフルエンザがあれ ほど高効率で広がったのかということだ」。

マウント・サイナイ医科大学のチームは すでに研究を開始した。Peter Palese は、 1918 年のウイルスを最初に復元した Adolfo Garcia-Sastre およびJeffery Taubenberger と共同で、ウイルス伝播の仕方を研究中であ る。彼らはフェレットを使った研究で、イン フルエンザウイルスのアミノ酸配列のうち 1 〜 2 個のアミノ酸が変化しただけで伝播が止 まることを見つけた。その結果はScienceに 掲載される。ゲノムのどの部分が伝播にか かわっているのかを突き止めることは「大流 行を引き起こすウイルス株かどうかを予測す るうえで非常に役立つ」と、世界保健機関 (WHO) と連携する国立インフルエンザセ ンター (オランダ、ロッテルダム) の Guus Rimmelzwaan は語る。

河岡たちも同じような方向で研究を進め ることにしており、ウイルスの一部を切り 貼りすることでどの部分が最も致死性にか かわっているのかを確定する計画である。

しかし、今回得られた最新の成果をもっ てしても世間の懸念はまだ和らいでいない。 ラトガーズ大学（米国ニュージャージー州） の細菌学者である Richard Ebright は、こ のウイルスは復元するべきでなかったと考
えている。「重大なのは、この復元ウイルス が現在少なくとも 2 か所の施設にあること だ」と彼はいう。そして、新たな研究はウ イルスが外部に流出するリスクを増大させ、 ほかの研究室が追従する「危険な前例」を 作ることになると主張する。

これと同様の内容の研究であっても対象が ありふれた病原体であれば、影響力の小さ い学術誌に掲載されるのが通例である、と Ebright はいう。そして、そもそもこの研究 が Nature 誌上で発表されること自体、注目 を集めたいがために高リスクの病原体を使お うとする研究グループの出現を促すことにな りかねず、ウイルスの拡散リスクを高めるこ とになる、とEbright は主張する。これと 似た意見をオフレコで話してくれた科学者は ほかにも複数いた。Nature の生物分野編集 主任である Ritu Dhand は、今回の論文掲 載決定の正当性を主張している。その理由は、 1918 年のウイルスがほかのインフルエンザ ウイルスと別格であるため、ヒトに対してこ れほど病原性が高い理由を解明することは科 学的関心事だと考えられる点にある。

1918 年のウイルス株に関する理解を深める ことが公衆衛生上の大きなメリットにつながる ことは、Galeも認めている。しかし、Galeはもっ と適切な研究方法があるのではないかと述べ、 また、歴史に対する興味が公衆衛生上の潜在 的メリットと同じくらいの推進力になって進め られる研究もあるだろうと考えている。

ハーバード大学医学系大学院 (米) のウ イルス学者であり軍備管理問題にも詳しい Jens Kuhn も胸中穏やかではない。「私が何 をいっても、どちらかの側に敵を作ること になってしまう」とKuhn はいう。「私は、 時に学術研究と軍備管理という 2 つ世世界 の板挟みになって途方に暮れてしまう」。

1. Taubenberger, J. K. et al. Nature $437,889.893$ (2005).

2. Tumpey, T.M. et al. Science $310,77.80$ (2005).

3. Kobasa, D. etal. Nature 445, 319.323 (2007). 